\title{
Program Pengembangan Kandang Intensif Ternak Sapi Gaduh Di Trenggalek
}

\author{
Susi Tri Wahyuni $\left.{ }^{1}\right)$, Kusni Hidayati ${ }^{2}$ ) \\ ${ }^{1}$ Program Studi Ekonomi Pembangunan, FEB, Ubhara Surabaya \\ ${ }^{2}$ Program Studi Akuntansi, FEB, Ubhara Surabaya \\ e-mail koresponden: 1. susitw@ubhara.ac.id, 2. Ibunaya@gmail.com
}

\begin{abstract}
ABSTRAK
Budaya Gaduh adalah sistem pemeliharaan dari pemilik modal ke pekerja ternak sapi dengan sistem bagi hasil dari nilai tambah yang dihasilkan dari pemeliharaan sapi tersebut. Pemberdayaan masyarakat berbasis budaya yang telah berkembang di daerah tersebut, akan lebih efektif dan lebih fleksibel terhadap striuk sosial yang telah berkembang di lingkungan masyarakat tersebut. Sehingga dapat mengoptimalkan produktivitas social fabric masyarakat setempat dengan mengintrodusir inovasi teknologi yang dapat meningkatkan nilai tambah ekonomis masyarakat tersebut tanpa merubah struktur social serta nilai-nilai sosial yang berlaku, sehingga akan mendapatkan dukungan dan partisipasi masyarakat yang optimal karena sesuai kondisi budaya setempat.

Metode yang dilakukan adalah dengan memberikan pelatihan dan pendampingan pembuatan kandang intensif pemeliharaan sapi, untuk meningkatkan manfaat dari limbah kotoran sapi menjadi bahan penerangan dan pengapian rumah tangga dan pupuk organik (kompos) dari kotoran sapi.

Hasil yang didapatkan adalah melalui kandang intensif, dapat dihasilkan biogas untuk penerangan dan pengapian rumah tangga dan pupuk kompos dari kotoran sapi yang bermanfaat bagi buruh pemelihara sapi (sapi gaduh) di rumahnya. Sehingga dapat meningkatkan nilai tambah ekonomis keperluan rumah tangga keluarga buruh pemelihara sapi gadug di desa Karangan, Kabupaten Trenggalek.
\end{abstract}

Kata Kunci : Budaya Gaduh, Community, Development, Trenggalek

\section{ABSTRACT}

The Gaduh culture is a system of raising capital from the owner of the capital to the cattle worker using a system for the results of the added value generated from raising the cow. Cultural-based community empowerment that has developed in the area will be more effective and more flexible towards the social characteristics that have developed in the community. So that it can optimize the social fabric productivity of the local community by introducing technological innovations that can increase the added economic value of the community without changing the social structure and prevailing social values, so that it will get optimal community support and participation because it is according to local cultural conditions.

The method used is to provide training and assistance in making intensive cowshed for cow maintenance, to increase the benefits of cow dung waste into household lighting and ignition materials and organic fertilizer (compost) from cow dung.

The results obtained are through intensive cages, biogas can be produced for household lighting and ignition and compost from cow dung which is useful for workers who keep cattle (rowdy cows) in their homes. So that it can increase the economic value added for the household needs of the family of gadug cattle keepers in Karangan village, Trenggalek Regency.

Key Word: "Budaya Gaduh", Community, Development, Trenggalek 


\section{PENDAHULUAN}

Hasil registrasi penduduk tahun 2019 menunjukkan bahwa jumlah penduduk Kabupaten Trenggalek sebesar 50 Juta Jiwa Terdiri dari 60 perempuan dan 40 laki-laki dengan tingkat pertumbuhan sebesar $7 \%$. Jumlah pendudukan yang relative besar tersebut merupakan salah satu potensi yang dapat dikembangkan dalam mendukung pengembangan kawasan peternakan agribis dengan jumlah RTP sapi 30 ribu.(Pemkab. Trenggalek, 2019).

Populasi sapi di Kabupaten Trenggalek menunjukkan kecenderungan meningkat dimana pada tahun 2013, jumlah populasi sapi sebesar 83.932 ekor, terdiri daeri: dewasa 41.228 ekor, muda 32.381 ekor dan anak 10.234 ekor, produksi anak (kelahiran adalah 1.031 ekor/tahun. Populasi sapi tersebar di 14 kecamatan dan sentra ternak sapi yaitu di kecamatan Tugu.

Sementara ini, masih ada usaha peternakan sapi yang diusahakan secara sambilan, walaupun nuansa agribisnisnya cukup terlihat. Penggantian dan penambahan populasi ternak produktif memerlukan sekitar 30-40\% dari total anak yang dihasilan. Secara alami rasio jenis kelamin anak yang dihasilan adalah seimbang. Oleh karena itu usaha sapi bibit dapat dimanfaatkan untuk menunjang program pengadaan sapi bakalan (60-70\% anak) yang saat ini mempunyai pasar sangat baik.

Budaya gaduh dalam pemeliharaan sapi merupakan tradisi yang telah lama berkembang di linkungan masyarakat Kabupaten Trenggalek dan masyarakat jawa pada umumnya. Kerja sama antara pemilik modal dan pekerja buruh pemelihara ternak telah berlangsung lama di lingkungan daerah tersebut. Untuk itu tim pengabdian Ubhara Surabaya melalui teknologi kandang intensif melaksanakan program pengabdian masyarakat di daerah tersebut, di desa Karangan, Kecamatan Karangan Kabupaten Trenggalek, agar terwujud percepatan nilai tambah ekonomis pada masyarakat pemelihara ternak gaduh sapi di daerah tersebut.

\section{METODE PELAKSANAAN}

Sasaran dari pelatihan ini adalah masyarakat pekerja pemeliharaan ternak sapi atau penggaduh sapi yang dipelihara secara konvensional yang pada umumnya masyarakat miskin pedesaan bekerja sebagai buruh tani dan buruh ternak, untuk latih dan menjadi pemelihara ternak sapi dengan kandang intensif yang dapat mempercepat proses penggemukan sapi agar diperoleh keuntungan yang maksimal dari pemeliharaah sapi gaduh tersebut. Adapun keuntungan ganda dari pemeliharaan gaduh sapi dengan teknologi kandng intensif adalah:

a. Pemelihara (penggaduh) dapat bahan bakar dan bahan penerangan dari gas yang dihasilkan dari kotoran sapi.

b. Pemelihara (penggaduh) dapat hasil tambahan berupa pupuk organik dari kotoran sapi yang dipelihara dengan kandang intensif tersebut. 
Kegiatan ini memfokuskan pada penyuluhan dan pendampingan pembuatan kandang intensif pemeliharaan sapi, bagi para penggaduh yang masih memelihara sapi dengan sistem kandang tradisional, untuk berubah menjadi pemeliharaan dengan sistem kandang intensif.

Kegiatan pengabdian ini akan menjadi bagian penting Fakultas Ekonomi program Studi Manajemen Universitas Bhayangkara Surabaya.

Metode kegiatan yang dilakukan pada pengabdian ini adalah :

1. Penyusunan proposal pada tahap ini, tim akan melakukan rancangan kegiatan pengabdian yaitu rancangan pembuatan kandang intensif bagi buru ternak sapi di lokasi yang telah ditentukan.

2. Pelaksanaan penyuluhan dan pendampingan pembuatan kandang intensif kepada kelompok masyarakat sasaran.

3. Pelaksanaan simulasi dan perhitungan modal kerja pembuatan kandang intersif pemeliharaan sapi gaduh di lokasi pengabdian.

Untuk mengetahui wujud keberhasilan pengabdian pada masyarakat, indikasi keberhasilan adalah apabila para buruh ternak sapi gadung tersebut, mampu membuat dan memanfaatkan hasil tambahan dari sistem kandang intensif ternak sapi yang diabdikan kepada kelompok masyarakat sasaran tersebut.

\section{HASIL DAN PEMBAHASAN}

Populasi sapi potong di Kabupaten Trenggalek menunjukkan kecenderungan meningkat dimana pada tahun 2019, jumlah populasi sapi potong sebesar 83.932 ekor, terdiri daeri: dewasa 41.228 ekor, muda 32.381 ekor dan anak 10.234 ekor, produksi anak (kelahiran adalah 1.031 ekor/tahun . Populasi sapi potong tersebar di 14 kecamatan dan sentra sapi potong yaitu di kecamatan Tugu. Adapun populasi bibit dilakukan oleh peternakan rakyat dengan tingkat kepemilikan yang relative kecil, yaitu sebesar antara 1-5 ekor/keluarga, walaupun ada yang memiliki sekitar 6-12 ekor/keluarga. Dibeberapa kawasan terdapat usaha sapi potong yang memiliki sapi potong lebih dari 50 -100 ekor. (Dinas Pertanian, Pemkab. Trenggalek, 2019).

Desa Karangan adalah suatu wilayah Desa yang berada di pinggiran kota Kabupaten Trenggalek, dari aspek pengembangan masyarakat, di Desa Karangan ini juga ada 3 Sekolah Dasar yaitu SDN Karangan I, SDN Karang II dan SDN Karnagan III, pada tingkat SMP ada SMPN I Karangan dan Madrasah ibtidaiyah dan madrasah tsanawiyah. 


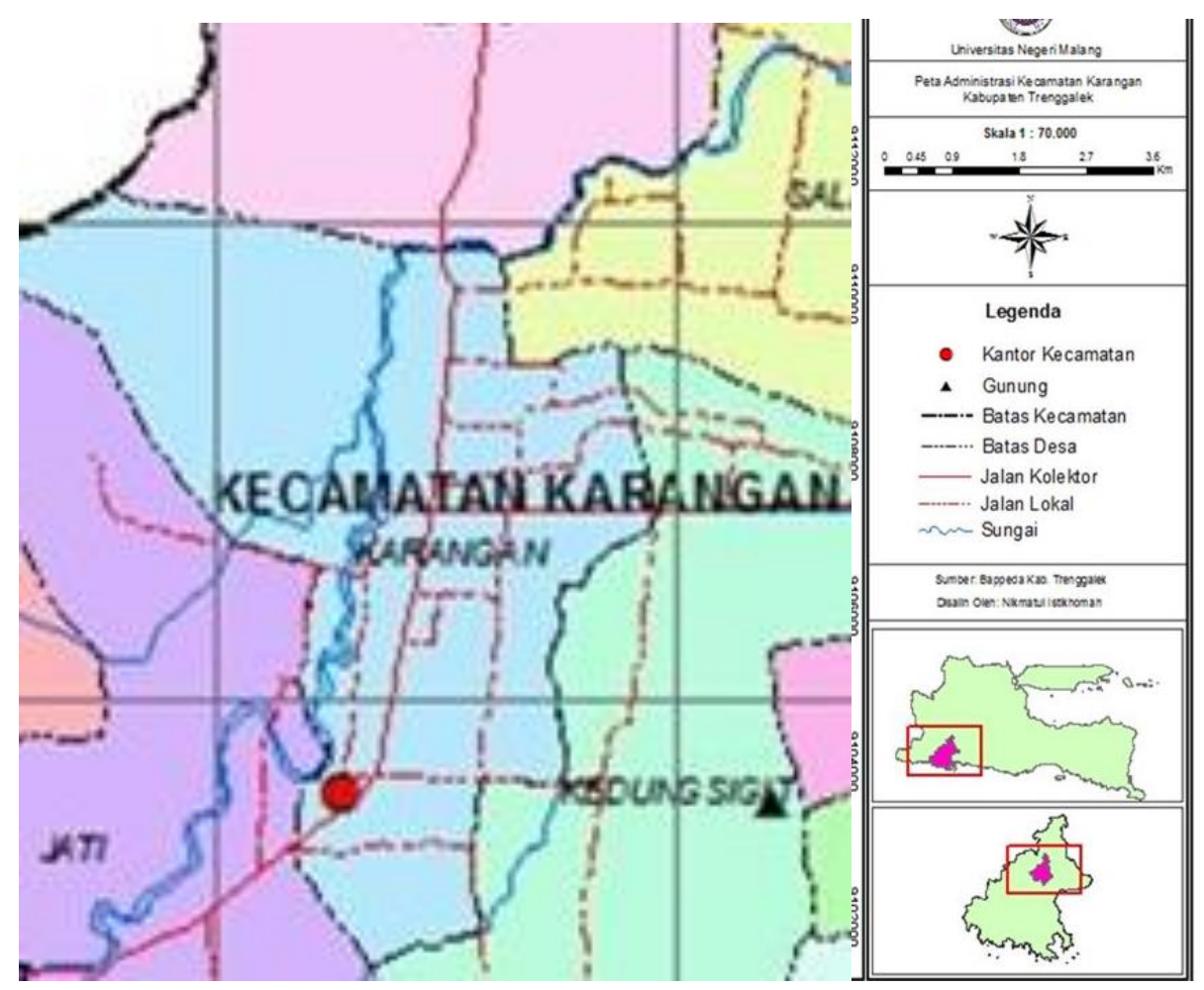

Gambar 3.1: Desa Karangan, Kabupaten Trenggalek

Desa Karangan merupakan desa telah memiliki sarana dan prasarana yang cukup memadai yaitu pusat keramaian pasar buah, pasar Wage, Pasar Subuh, dan beberapa produk fasilitas perdagangan lainnya.

\subsection{Pemeliharaan Sapi Dengan Sistem Gaduh.}

Model pemeliharaan sapi di lingkungan Desa Karangan Kabupaten Trenggalek sebagian besar dilakukan dengan sistem Gaduh, sapi masih merupakan investasi besar di lingkungan masyarakat Desa Karangan, mereka menyebutnya sebagai Rojo Koyo ( dapat dapat diartikan raja kaya) di lingkungan Desa Karangan Kabupaten Trenggalek (Manti. I, Azmi, E.Priyotomo,dan D. Sitompul. 2003). Selain itu para pemilik sapi pada umumnya bukan murni pekerja tani/peternakan yang penghasilannya mengandalkan dari hasil peternakan sapi. Sehingga pada umumnya pelaksanaan pemeliharaan ternak sapi di lakukan secara tidak langsung dengan cara sistem bagi hasil dengan pekerja ternak sapi yang ada di lingkungan masyarakat tersebut. Pada umumnya pemeliharaan sapi dari pemilik sapi diserahkan kepada kenalan atau sanak saudara yang dipercaya untuk memelihara ternak sapi yang dititipkan atau di gaduhkan. 


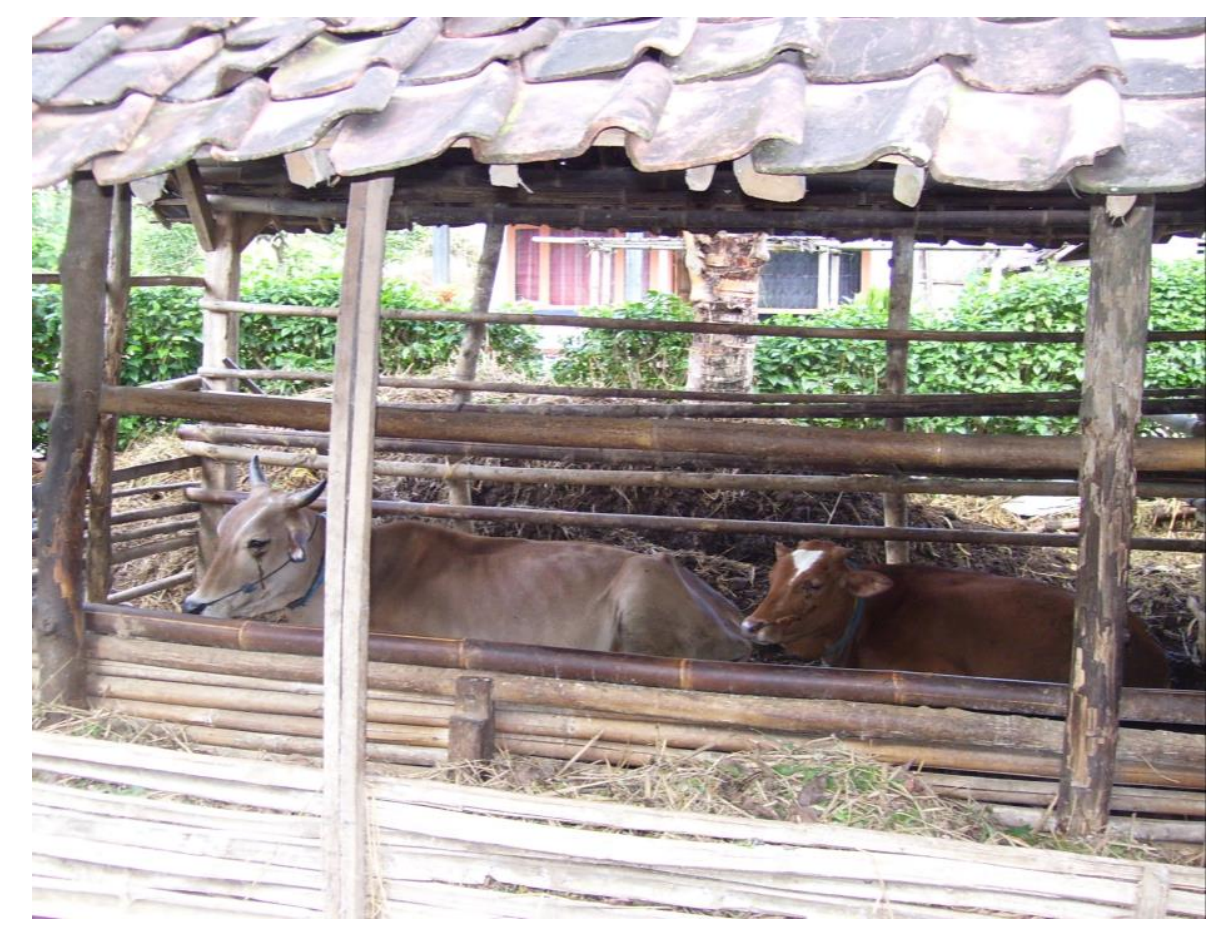

\section{Gambar 3.2. Sistem Pemeliharaan Gaduh Sapi Konvensional.}

Pemeliharaan sapi dengan sistem gaduh memungkinkan terjadi akses model dari pemilik sapi ke buruh ternak sapi dengan perhitungan sebagai berikut:

1. Untuk sapi indukan, bila telah melahirkan anak maka anak sapi tersebut nilainya di bagi 2, separuh untuk pemilik dan separuh untuk pemelihara. Sistem seperti ini umum berlaku di masyarakat Kabupaten Trenggalek, dan telah di terima sebagai sistem ekonomi yang dianggap adil oleh masyarakat setempat.

2. Untuk sapi pejantan, seorang pemilik sapi tidak harus menggaduhkan sapi betina untuk memperoleh hasil dari hasil pemeliharaan sapi yang digaduhkan. Sistem pemeliharaan untuk sapi jantan biasanya untuk jenih sapi potong, hingga hitungan pembagian hasil kerja sistem gaduh ini diberikan dari selisih harga beli dengan harga jual untuk kemudian, keuntungannya di bagi 2, separuh untuk pemilik dan separuhnya lagi untuk buruh ternak atau pemelihara.

a. Khusus untuk jenis sapi potong (jantan) untuk menghitung hasil dalam suatu kawasan. Harus diperhitungkan periode pemeliharaan dalam suatu kawasan atau komunitas perhitungannya hendaknya dilakukan selama lima tahun, selama 5 (lima) tahun dengan pertimbangan bahwa tenggang waktu tersebut pemeliharaan sapi potong dapat diperoleh keuntungan yang maksimal dan pada tahun ke lima peternak sapi potong mempunyai kemandirian pengelolaan sapi potong, selanjutnya modal awal dapat digulirkan kepada kelompok peternak lainnya yang membutuhkan bantuan modal, dengan demikian diharapkan adanya pengembangan wilayah penyebaran ternak sekaligus peningkatan produksi ternak sapi bakalan dan daging. 
b. Namun demikian untuk pemeliharaan sapi jantan (potong) masing-masing keluarga atau $\mathrm{KK}$, dapat dilakukan perhitungan pengembangan penggemukan selama masing-masing 3 bulan, 6 bulan dan 9 bulan untuk kelompok keluarga miskin tersebut. Hal ini karena, sistem pemeliharaan gaduh pada masingmasing KK atau keluarga peternak pemelihara hasilnya dapat langsung dirasakan berdasarkan perkembangan pertumbuhan sapi, yang dapat dihitung dari tumbuhnya berat badan sapi. Sehingga keuntungan yang diperoleh dapat dihitung dari peningkatan harga daging sapi tersebut, per 3 bulan, 6 bulan dan 9 bulan, selama pemeliharaan yang dilakukan oleh penduduk miskin yang mendapat kepercayaan untuk menggaduh sapi yang diternakkan/dipelihara. Hal ini terjadi karena pada umumnya, para buruh pemelihara sapi tersebut, umumnya juga sebagai buruh tani dan buruh serabutan (pekerjaan tidak menentu) lainnya, kemampuan dalam memelihara sapi setiap keluarga adalah antara 2 sampai maksimal 5 ekor sapi.

Kemampuan memelihara hanya sampai sejumlah maksimal 5 sapi tersebut, karena pekerjaan memelihara sapi tersebut, tidak bisa dilakukan secara khusus. Pemeliharaan sapi dengan cara nyambi ini, selain dapat memberikan manfaat yang lebih optimal bagi kerja pemelihara sapi. Karena sapi tiap hari selain harus pakan dari dried rice straw yang dapat disimpan dalam waktu lama, akan tetapi juga harus diberi pakan rumput rumput segar setiap harinya yang dapat diperoleh dari sawah atau tegalan di sekitar rumah.

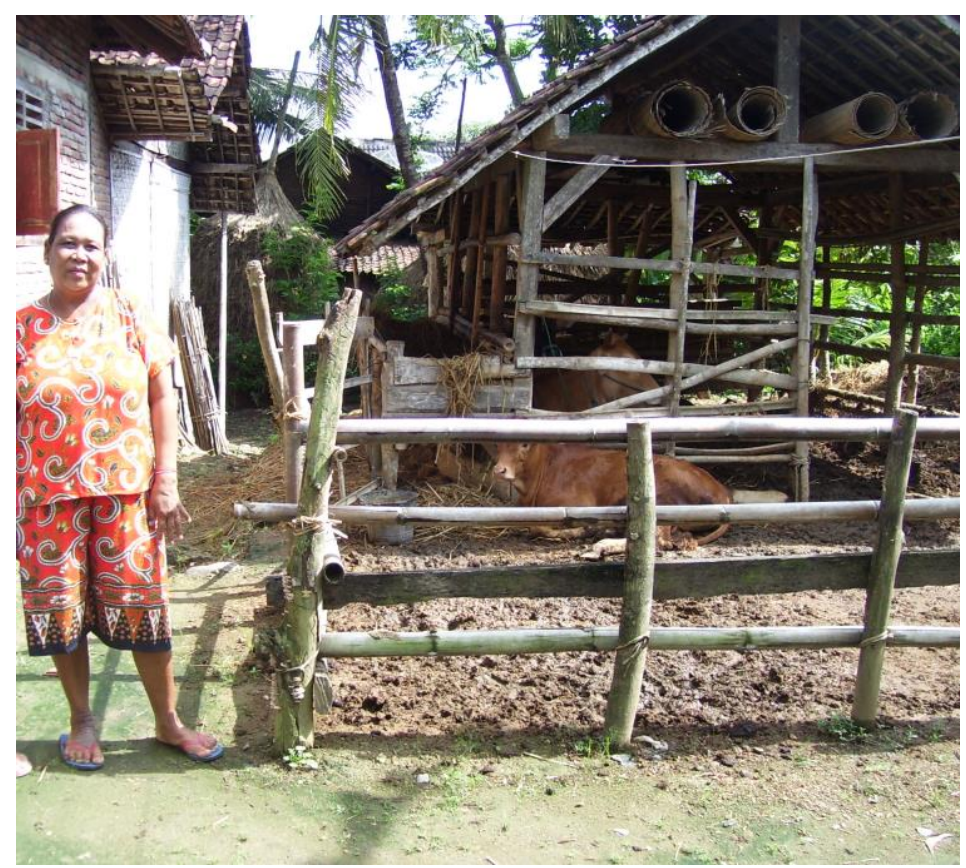

Gambar 3.4. Penggaduh Dengan Sistem Kandang Konvensional 


\subsection{Pelaksanaan Program}

Program pengabdian kepada masyarakat yang diterapkan bagi kelopok buruh ternak sapi yang menjadi sasaran dari program ini Pengembangan Model Kandang Intensif bagi buruh tani ternak gaduh di Kabupaten Trenggalek. Sistem Kandang intensifikasi pemeliharaan sapi bagi para penggaduh ternak sapi bisa memperoleh keuntungan yang maksimal bagi kebutuhan hidupnya sehari-hari dengan memelihara sapi tersebut, karena dengan mengembangkan sistem perkandangan yang efisien bermanfaat ganda, sehingga dapat meningkatkan kesejahteraan petani penggaduh sapi tersebut, secara efisien, optimal dan mampu memberdayakan ekonomi mereka dengan tambahan manfaat dari pemeliharaan ternak sapi dengan sistem kandang intensif (Dwiyanto,K., A. Priyanti dan Zaenudin. 1996). Secara visual pembuatan kandang yang bermanfaat ganda untuk produksi biogas tersebut, dapat dilihat dalam gambar sebagai berikut:

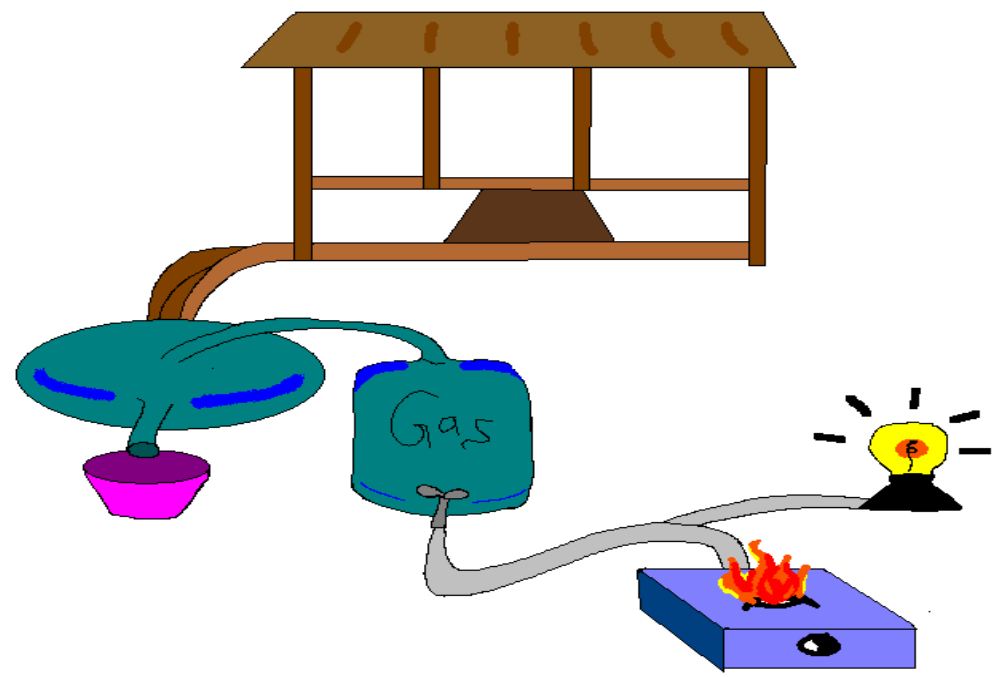

\section{Gambar 3.5. Model Kandang Intensif untuk Sapi Gaduhan}

Pembuatan Kandang intensif, tipe kandang yang dibutuhkan intensif daya tahan kandang sampai dengan lima tahun, dimana untuk sapi potong bibit disediakan kandang perawatan, kandang persiapan melahirkan dan kandang pedet. Membutuhkan bentuk, type dan luas kandang yang sama dengan satu ekor yaitu:

a. Luas kandang $160 \mathrm{~cm} \times 135 \mathrm{~cm}$

b. Tempat pakan berukuran $95 \mathrm{~cm}$ x $40 \mathrm{~cm}$ x $40 \mathrm{~cm}$

c. Tempat minum berukuran $40 \mathrm{~cm} \times 40 \mathrm{~cm} \times 40 \mathrm{~cm}$

d. Kemiringan kandang $5^{0}$

Untuk meningkatkan intensifikasi manfaat pemeliharaan ternak sapi potong, ini dapat dikembangkan untuk kepentingan kebutuhan biogas rumah tangga pemelihara 
ternak sapi tersebut. Kandang intensif tersebut, dapat memberikan hasil yang optimal bagi para penggaduh sapi, dan hal ini penting dikembangkan agar kebutuhan gas rumah tangga untuk pengapian keperluan rumah tangga, dapat diperoleh dari sistem kandang yang dibuat untuk produksi biogas dari hasil pemeliharaan sapi ini. Dengan demikian diharapkan akses modal (keuntungan) yang peroleh penggaduh sapi tersebut, dapat memberikan keuntungan yang lebih besar.

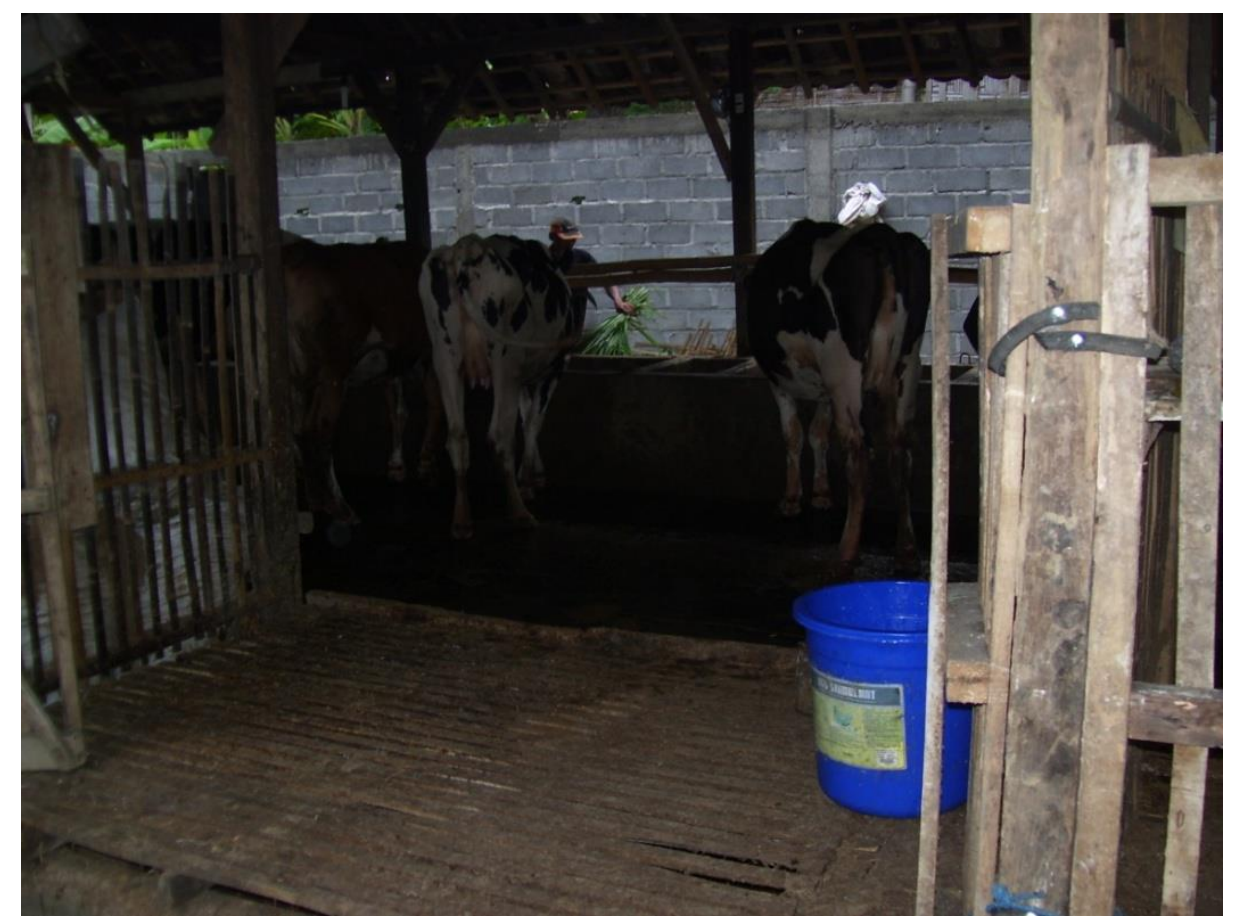

\section{Gambar: 3.6. Pembuatan Kandang Internsif Sederhana Gaduh Sapi}

Dengan disediakannya sistem kandang biogas tersebut, memungkinkan penggaduh sapi menggunakan kotoran sapi untuk penyediaan kebutuhan gas sehari-hari untuk kepentingan memasak, kepentingan penerangan, dan berbagai kebutuhan lain yang dihasilkan dari biogas hasil ternak sapi tersebut. Sehingga masyarakat penggaduh yang umumnya masih miskin dengan memelihara sapi tersebut, dapat memperoleh manfaat lain secara rutin selama melakukan pemeliharaan sapi. Keuntungan yang diperoleh dari biogas pemeliharaan sapi tersebut, setidaknya peternak tidak perlu lagi mengeluarkan ongkos rutin untuk kebutuhan penerangan dan memasak serta waktu dan tenaganya bisa lebih banyak untuk dapat memelihara sapi secara lebih intensif.

\section{Manfaat Pupuk Organic dari Kandang Intensif.}

Manfaat lebih lanjut, yang dapat dioptimalkan dari sistem perkandangan intensif tersebut adalah pemanfaatan kotoran sapi untuk pupuk. Pemanfaat untuk pupuk ini, dilakukan setelah proses pembuatan biogas selesai, sehingga sebenarnya pembuatan pupuk organik ini merupakan produk lanjutan dari proses pembuatan biogas. Kotoran 
sapi yang telah diproses menjadi biogas melalui septitank, diproses lebih lanjut untuk menghasilkan pupuk yaitu pupuk organik kotoran sapi.

Dalam proses ini kotoran sapi dari dalam biogas, dialirkan ke luar dari septitank untuk kemudian dikeringkan dan diproses menjadi pupuk organik yang dapat dikemas dalam produk dagang tertentu dan dapat dijual ke masyarakat, oelh penggaduh sapi yang bersangkutan. Proses ini dapat memberikan tambahan penghasilan yang cukup ekonomis, bagi peternak penggaduh karena bisa memberikan keuntungan lebih lanjut dari hasil pemeliharaan sapi, para penggaduh. Selain itu pekerja peternak sapi, dapat menggunakan pupuknya tersebut untuk kepentingan pertaniannya sendiri, bila petani tersebut memiliki lahan pertanian yang perlu disuburkan dari pupuk biogas kotoran sapi tersebut.

Pola ini dapat menjadi peluang usaha penggaduh ternak sapi yang dikembangkan dalam suatu wilayah komunitas tertentu sehingga mampu menghasilkan keuntungan tambahan atau peluang usaha tambahan dari hasil usaha ternak sapi tersebut.

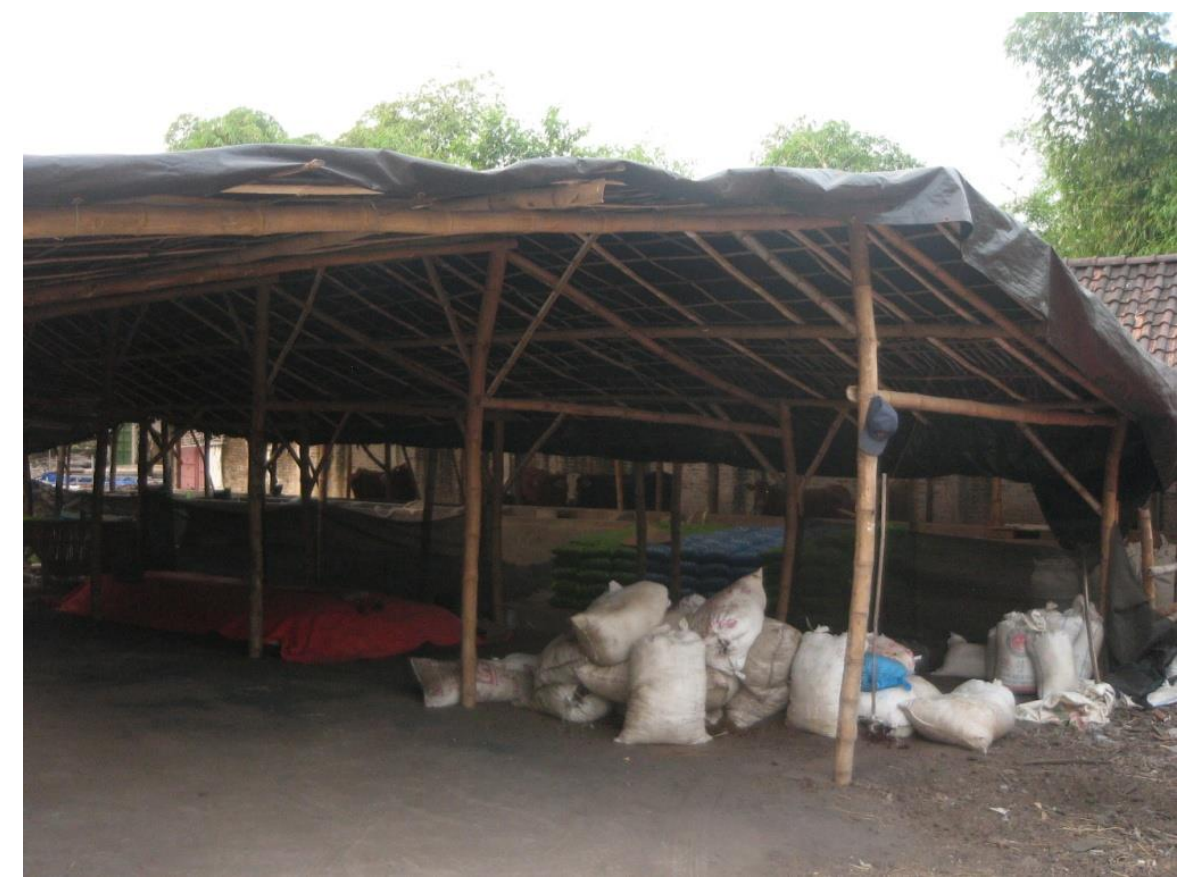

Gambar 3.7. Kemasan sederhana pupuk organic dari hasil ternak sapi, bagi para penggaduh sapi

\section{SIMPULAN}

1. Biaya investasi untuk peternakan sapi dengan sistem gaduh (khususnya bagi keluarga miskin) perumah tangga diperkirakan kurang lebih antara Rp 3.000.000,sampai dengan Rp. 5.000.000,- termasuk sistem kandang biogas yang dibutuhkan, untuk pemeliharaan sebanyak antara 2 sampai 5 ekor berdasarkan kemampuan satu keluarga untuk merawat ternak sapi tersebut. Biaya sebesar tersebut, menjadi sangat 
berat bagi petani miskin di lingkungan perdesaan, karena ketiadaan biaya untuk investasi sebesar itu. Sehingga sistem gaduh komprehensif atau sistem pemeliharaan sapi + kandang biogas dan pupuk kompos, sangat memungkinkan untuk meningkatkan para penggaduh yang umumnya masih miskin yang bekerja secara riil mengeluarkan tenaga dan pikirannya secara langsung untuk memelihara sapi yang di gaduh.

2. Setiap keluarga miskin, yang umumnya bekerja sebagai buruh tani dan pekerja serabutan di daerah perdesaan hanya memiliki kemampuan memelihara sapi maksimal 5 ekor, untuk masing-masing keluarga. Sehingga pemberian beban melampaui jumlah tersebut, akan semakin memberatkan petani pemelihara karena ada kegiatan lain yang tidak tetap akan tetapi bisa secara langsung memberikan pendapatan untuk pemenuhan kebutuhan konsumsinya sehari-hari. Oleh karena itu sebagai kompensasi atas tenaga dan pikirannya untuk memelihara sapi, perlu mendapatkan imbalan tambahan kebutuhannya sehari-hari melalui sistem gaduh komprehensif yaitu memelihara sapi gaduh + kandang intensif, untuk mendapatkan nilai tambah ekonomis penggaduh dari biogas dan pupuk kompos yang dihasilkan.

3. Bagi keluarga petani miskin, yang tidak memiliki akses modal maupun informasi atau jaringan yang memadai untuk menjadi pedagang sapi, atau mengelola industri peternakan yang memungkinkan mereka dapat berkolaborasi serta mempengaruhi harga beli dan harga jual sapi. Dapat dilakukan pemeliharaan sapi dengan sistem gaduh saja, yang memungkinkan mereka bisa melakukan pemeliharaan sapi, serta memenuhi kebutuhannya dengan sistem gaduh komprehensif, yang memungkinkan mereka dapat memelihara sapi dengan keuntungan ekonomis yang lebih tinggi bukan hanya dari sapi gaduh tersebut.

4. Untuk dapat meningkatkan kesejahteraan penggaduh ternak yang masih miskin berbasis pemeliharaan sapi tersebut, model yang dapat dikembangkan dalam rangka mengentaskan kemiskinan mereka yaitu melalui cara kandang intensifikasi dan ekstensifikasi hasil usaha ternak sapi melalui hasil kandang biogas dan pupuk organik yang dihasilkannya. Pengembangan Kandang Biogas dengan teknologi sederhana, untuk pemenuhan energi rumah tangga ternak gaduh, baik untuk kepentingan pengapian memasak sehari-hari maupun untuk kepentingan penerangan rumah sehari-hari, serta pupuk kompos hasil kotoran sapi. Sangat memungkinkan peningkatan tambahan penghasilan penggaduh ternak sapi yang bersangkutan, serta peningkatan ekonomi mereka.

\section{UCAPAN TERIMA KASIH}

Puji Syukur kehadirat Allah SWT, Alhamdulillah Kami tim dari Universitas Bhayangkara Surabaya terutama bagi Program Studi Manajemen Fakultas Ekonomi yang telah dapat menyelesaikan kegiatan Pengabdian Kepada Masyarakat di desa Karangan Kabupaten Trenggalek. Semoga tim kami setelah melaksanakan kegiatan ini 
bisa mensuport kepada masyarakat desa Karangan dan memberi semangat kepada masyarakat penggaduh ternak sapi di daerah tersebut.

\section{DAFTAR PUSTAKA}

Dinas Pertanian, 2019, Trenggalek Dalam Angkat, Dinas Pertanian Pemerintah Kabupaten, Trenggalek.

Dwiyanto,K., A. Priyanti dan Zaenudin. 1996. Pengembangan ternak berwawasan agribisnis pedesaan dengan memanfaatkan limbah pertanian dan pemeliharaan bibit yang tepat. Jurnal Penelitian dan Pengembangan Pertanian. XV: 15.

Manti. I, Azmi, E.Priyotomo,dan D. Sitompul. 2003. Kajian sosial ekonomi sistem integrasi sapi dengan kelapa sawit (SISKA). Prosiding Lokakarya Nasional Sistem Integrasi Kelapa - Sapi. Bengkulu, September 2003. Pusat Penelitian dan Pengembangan Peternakan. Bogor. 